\title{
Research on Innovation and Risk Management of Logistics Financial Business
}

\author{
Xueyuan Wang, Yifei Geng, Zhining Zhang \\ School of Management Engineering, Zhengzhou University, Zhengzhou 450001, China
}

Keyword: Logistics finance; Creativity model; Risk management

\begin{abstract}
As the logistics industry in China plays an increasingly important role, issues restricting the development of logistics-related are also increasingly valued by people. The current development and risks of the domestic logistics finance are studied. And from the business point of view, the paper focuses on several logistics financial innovative models mainly used currently. Then these models' risks in operation have been elaborated, and combined consult relevant literature, by inference concluded some risk-averse measures, the paper tries to help companies have better and faster development.
\end{abstract}

\section{INTRODUCTION}

During the current development of China's economy, smallest and medium-sized enterprises have developed very slowly due to lack of financing or financing difficulties (Yan He,2015). It is understood that the domestic small and medium-sized enterprises in pays taxes, GDP and absorb employment share more than 50\% of the share, but not matching is the small and medium-sized enterprise loans accounted for only $16 \%$ of the domestic main lending institutions, and more than $66.6 \%$ of the companies think financing difficulties hinder its further development is the key to the problem. In zhejiang province as an example, according to the small and medium-sized enterprises in zhejiang province, according to data released in the first half of 2015, zhejiang province the number of small and medium-sized enterprises above designated size, the scale continue to faster growth, and growth is higher than that of large enterprises (Peng Cui, Cong Li,2013).

For the vast majority of small and medium-sized enterprises, due to insufficient financing, the logistics finance business has been generated (Yan Cheng,2013). The relatively small size, on the other hand, because the enterprise itself or the reality of development is not perfect, the fixed assets is not much, right now, enterprises prefer "asset light" model of development to alleviate this situation, this will directly cause the situation to obtain funds cannot smoothly through the way of mortgage (Peipei Tang,2015). However, the proposal of logistics finance can solve this problem well. For financial logistics service business, it is the demand of the development of the present domestic, its fundamental purpose is to effectively solve the problem of financing difficulties, and in this process, it can also help small and medium-sized enterprise more flexible use of the short of raw materials and finished goods, will they become can be temporarily corporate use of funds, so as to optimize enterprise resource (Gang Wu,2014).

This paper discusses logistics financial innovation and risk research at home and abroad, analyses the development of the enterprise logistics financial valuable reference points, avoid risk, which can guide enterprise better and faster development (Daozhi Zhao, Mapeng Bai,2012). The elaboration and related analysis of logistics financial risk can effectively enable enterprises and financial institutions to cooperate well, reduce operating costs, improve operation efficiency and ensure steady economic development (Xuejian Chu,2013).

\section{THE MEANING OF LOGISTICS FINANCE}

It refers to the movement of money funds in the field of logistics, through the application and development of various financial products, through the application and development of various financial products. It is an innovative third-party logistics service products, for financial institutions, enterprises and third-party logistics service supply chain to provide close cooperation between business provide a good platform, so that you can achieve win-win cooperation (Suye Wang,2015).

\section{CHINA'S LOGISTICS FINANCIAL BUSINESS DEVELOPMENT STATUS}

In view of the current development of logistics finance business in China, the operation efficiency of this business is not bad. The logistics finance business effectively solves some problems in the capital flow (Shuikun Hong,2015). In addition, the business is accompanied by a bank and common development of enterprises, Banks groped through constant innovation and development of all kinds of business innovation and perfect the various operations to attract a large number of deposits, increase income (Weiguang Shen, Li Yu,2012).

According to the statistical data of the first quarter of 2013, financial institutions within the territory of China (mainly refers to the commercial Banks) of the overall credit condition is good, the bad credit rate is only $0.96 \%$, compared with the same period last year increased by $0.02 \%$. Table 1 is the calculation.

According to the above table analysis, it is easy to see that joint-stock Banks have done better in this respect. The smaller of joint-stock commercial Banks is more diversified and conducive to the innovation of enterprise business products (Siyu Geng,2013). In the current logistics finance business, logistics finance is more suitable to operate under the joint-stock commercial Banks. In the case of the successful operation of the 
joint-stock commercial Banks, other commercial Banks should improve the deficiencies in all aspects according

Table 1 The credit status of major com

\begin{tabular}{|l|l|l|}
\hline Commercial Bank & $\begin{array}{l}\text { Non-performing loan } \\
\text { balance (\$100 million) }\end{array}$ & $\begin{array}{l}\text { Non-performing } \\
\text { loan ratio (\%) }\end{array}$ \\
\hline Big commercial Banks & 3241 & 0.98 \\
\hline Joint-stock commercial Banks & 896 & 0.77 \\
\hline City commercial Bank & 454 & 0.83 \\
\hline Rural commercial Bank & 612 & 1.73 \\
\hline Foreign Banks & 62 & 0.59 \\
\hline
\end{tabular}

In response to the relevant requirements of the state, the Chinese federation has carried out a key survey of some representative logistics enterprises in China and ranked the top 50 according to the data. In view of the development of China's current logistics market, logistics enterprises can be properly divided according to their own service characteristics and quantity, as shown in figure 2 .

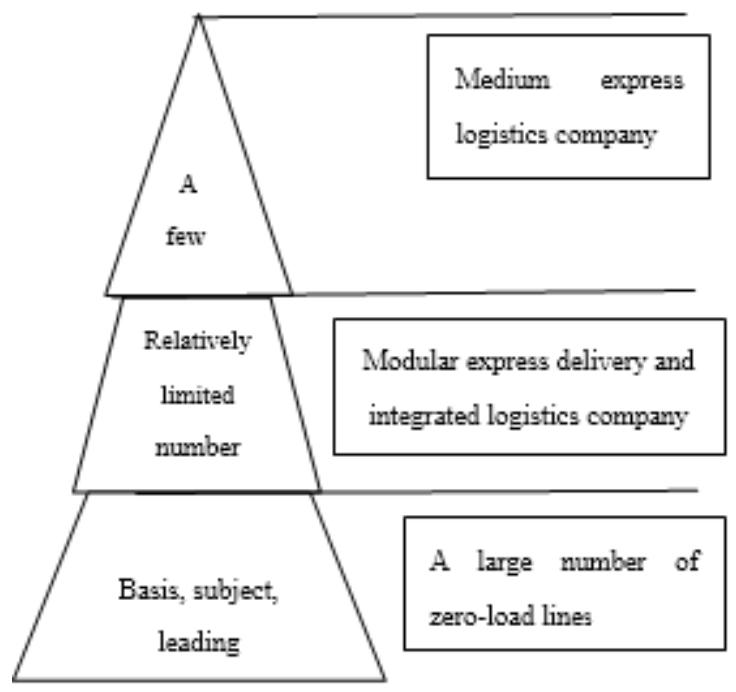

FIG. 1 composition structure of Chinese logistics enterprises

At present, the logistics financial services of domestic scale are mainly controlled by some state-owned enterprises (Puhe Liu,2013). Due to the early development time of state-owned enterprises, high visibility and strong financial background, it is easier to gain advantages in the competition. Small and medium-sized logistics enterprises themselves are difficult to cooperate with Banks due to short development time, immature business and some credit conditions (Xiaofeng Qin, 2012).

\section{COMPARATIVE ANALYSIS OF LOGISTICS FINANCIAL INNOVATION MODE}

\subsection{Traditional inventory pledge business model}

For the vast majority of small and medium-sized enterprises that lack operating capital, they generally have difficulty getting loans from Banks. Lack of small to their own characteristics to reduce the bad credit

(Shengrong Dong, Junlong Jia,2012).

and medium-sized enterprises of real estate can be mortgaged to the bank the company temporarily need not raw materials, semi-finished or finished products to obtain financing (Gang Wang,2015). Traditional mortgage financing is the enterprise must take their own real estate as collateral, or any other qualified for guarantee of the company to do for their financing guarantee, otherwise the bank will not for small and medium-sized enterprise financing (Junhong Hao,2012).

Static and dynamic pledge mode

In the emerging business model for inventory impawn financing, according to the supply chain between upstream and downstream enterprises in the real personal property, the bank can be movable property as collateral to corporate finance, specific and can be divided into static and dynamic pledge (Nan Wang,2012).

Static pledge is refers to the financing needs of enterprise control of the transfer of the mortgaged property to the third party logistics enterprises to obtain financing, only the enterprise loans, control of the goods will be returned to enterprise. This kind of financing way can greatly reduce the loan risk of third party logistics enterprise, make the rights and interests of the third party logistics enterprises receive better protection, but through the actual inspection operation, some problems also gradually exposed. For example, according to the regulation, enterprise before pay off the loan is not those used to control of the mortgage goods, if the mortgaged property is raw material, so the daily production and operation of the enterprise will be because of the lack of raw materials and make the enterprise operating difficulties, enterprises can not get enough revenues would not pay generation, eventually damage the relevant rights and interests of the third party logistics enterprise. So now more static mortgages will appear in the inventory to obtain financing situation, and companies used to make the pledge of stock must also conform to the requirements and has the characteristics of the daily without change. (Lei Liu,2013).

Dynamic pledge refers to the existence form of small and medium enterprises that have financing needs to the bank to be submitted to the bank in the period of pledge (Wenhang Xing,2014).

It is not hard to see the difference between dynamic and static pledge. Static pledge of movable property pledge before the enterprise shall repay the loans is not change, which cannot be displacement, so the static 
pledge also becomes the most basic business model in logistics financial business, and that the pledge cannot be replacement out the provisions of the inventory model is given. So dynamic pledge is developed on the basis of static pledge of the new model, in this mode, the bank is usually a mortgage of movable property of the enterprise set up the standard amount, only more than the amount of parts can be replacement, such not only can safeguard their own rights and interests are not violated, and reduces the risk (Shunxiang Teng, Zhizhong Peng,2015).
Relative to the static pledge, dynamic pledge to enterprise's daily business activities affect the weaker, and avoids the enterprises pay extra in the form of goods exchange margin, greatly improving the inventory utilization. So dynamic pledge apply in addition to the inventory without other limits of those who have the financing needs of small and medium-sized enterprises, but the bank pledged to the enterprise inventory is has the certain requirement, its advantages is that inventory can often be replacement.

Table 2 Comparison between static pledge and dynamic pledge

\begin{tabular}{|c|c|c|c|}
\hline & $\begin{array}{l}\text { Comparison of the } \\
\text { content }\end{array}$ & Static pledge & Dynamic pledge \\
\hline \multirow{6}{*}{$\begin{array}{l}\text { no } \\
\text { Same as } \\
\text { point }\end{array}$} & causes & $\begin{array}{l}\text { Lack of guarantee, cred } \\
\text { low small and medium-size } \\
\text { enterprises financin } \\
\text { difficulties, and curre } \\
\text { assets occupy a larg } \\
\text { amount of funds }\end{array}$ & $\begin{array}{l}\text { Different types of movable } \\
\text { property in different stages are } \\
\text { required to timely redeem and } \\
\text { tparticipate in the production } \\
\text { eand operation of the supply } \\
\text { chain }\end{array}$ \\
\hline & Main service objects & Trade client & Production customer \\
\hline & Risk identification & Pre-credit chattel audit & $\begin{array}{l}\text { Review and evaluate the whole } \\
\text { process of credit }\end{array}$ \\
\hline & Form of pledge & unity & Variety, mix \\
\hline & The pledge mode & Specific inventory patterns & Check the inv \\
\hline & Theredemption way & Recovery margin & Chattel redemption \\
\hline $\begin{array}{l}\text { phase } \\
\text { Same as } \\
\text { point }\end{array}$ & \multicolumn{3}{|c|}{$\begin{array}{l}\text { (1) It is the trade background for the whole supply chain to provide the } \\
\text { chattel credit for the small and medium-sized enterprises; } \\
\text { (2) To introduce the funds of core enterprises as risk control variables; } \\
\text { (3) There exists credit risk, operational risk and market risk. } \\
\text { (4) The selection of third-party service enterprises to provide professional } \\
\text { services such as warehousing, supervision and risk assessment; } \\
\text { (5) The stakeholders are basically the same, including financing } \\
\text { enterprises, financial institutions, third-party service enterprises and core } \\
\text { enterprises; } \\
\text { (6) With good business environment and efficient supply chain } \\
\text { management level; } \\
\text { (7) In order to effectively suppress information asymmetry, the service } \\
\text { platform needs to have advanced information system as support. }\end{array}$} \\
\hline
\end{tabular}

\subsection{Innovative logistics pledge mode and analysis}

\subsubsection{Insurance warehouse mode}

The business of confirming warehouse refers to a special kind of negotiable instrument business model that occurs between Banks, dealers and suppliers.

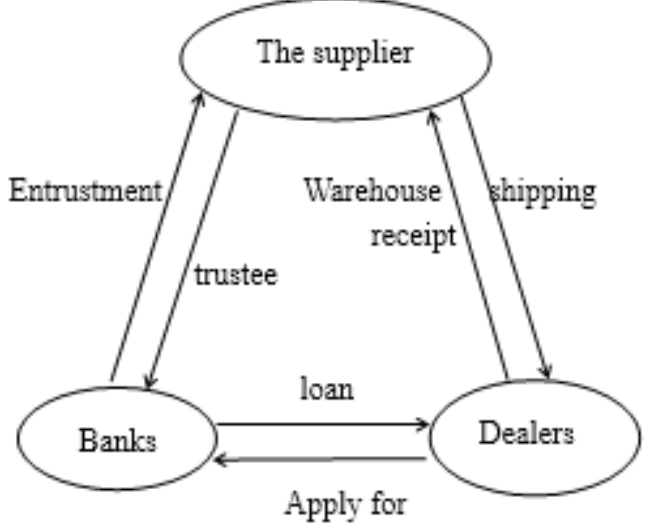

FIG. 2 Business flow chart of protection warehouse mode

\subsubsection{Land warehouse mode}

Sea Liu Cang pattern is more complicated, as the name implies, in the business enterprise for the pledge of goods may experience intermodal transport or point line, in the process of the company will send professional regulators of the entire regulatory.

\subsubsection{Other innovative modes}

In addition to these two typical logistics financial business models, some innovative forms are also extremely competitive. Instead of purchasing, for example, in this mode, have the funds difficult enterprises entrust the third party logistics enterprise to the specified by the purchaser to purchase, logistics enterprises have the disposition of the goods, only to the logistics enterprises pay money to obtain the needed goods provided. The characteristics of this innovative impawn financing model is the logistics company to replace the purchasing company to shoulder the responsibility, to monitor the goods, even at the same time achieve a higher degree of integration between and 
among logistics, cash flow, information flow and liberated the small and medium-sized enterprises, more Banks share the risk.

\section{LOGISTICS FINANCIAL INNOVATION MODEL RISK IDENTIFICATION}

In order to help enterprises to better the application of these operations, reduce the management risk, we first need to do is to properly identify may bring the risk of loss for the company, the company's losses to a minimum. Directed at several pledge regulatory process of the possible risk, through the further research and analysis, put forward some Suggestions, in order to logistics finance in the financing of small and medium-sized enterprises have greater help (Zheng Liu,2014).

Logistics financial innovation model is accompanied by further development of logistics industry, which is a value-added product of third-party logistics. It combines Banks, enterprises, and third-party logistics to find common ground. From the perspective of financing enterprises, due to the bank to manage the mortgaged property and the enterprise loans, so a greater risk of bank management, the risk from the enterprise internal and external two aspects, which creates a bank takes more effort into this piece of business risk management, but for now the little effect.

\section{RISK PREVENTION MEASURES FOR LOGISTICS FINANCIAL BUSINESS}

Under the big problem of financial logistics, based on the importance of financial logistics for the development of logistics enterprises in China, it is necessary to carry out in-depth research on risk control. In the us subprime mortgage crisis triggered by the global economic crisis's big background, our country small and medium-sized enterprises, especially those small and medium-sized enterprises engaged in foreign trade export business, at any time may face the risk of capital chain rupture. Therefore, it is of great significance to improve the risk management ability of logistics financial business, reduce business risks and encourage Banks to actively provide financing blood transfusion for small and medium-sized enterprises.

Third-party logistics enterprises in providing clients with financial logistics service, is the important basis to the application for the customer to have a full understanding of, and use of the established credit mechanism, effective credit management with the customers, established long-term cooperative relationship with this. Due to information asymmetry caused by bank loans into a bad situation, need to the third party logistics to provide reliable information for Banks, to establish a long-term relations of cooperation, win the trust of each other, can more properly solve the problem of efficiency in the financial services.

Logistics enterprises can from the bank credit evaluation and risk control methods adopted by the guide, based on the customer credit file management, customer information collection, customer credit archive management, etc., comprehensive all-round credit of customer credit management, to the financing project more effective risk assessment. In order to avoid the credit risk and market risk, logistics enterprises should pay attention to when choosing the pledge of the enterprises have to be strictly confirm the confrontation between the ownership of things, only belong to the investor of material to pledge. Logistics enterprises to examine the legitimacy of the source materials, clear the pledgor, the custodian, the pledgee related rights and obligations and legal relationship, for acceptance, confirmation, the goods quality, replacement and deregulation important link for the control of key management.

\section{CONCLUSIONS}

This paper in the first two part introduces the research status quo of logistics financial business in our country, and then in the third part focuses on the traditional business models and innovation of logistics financial model, and contrast analysis of the characteristics of their respective business. Then, in part 4 of the thesis, the risk sources in the business are analyzed and introduced. Finally, in part 5, I present my own views on risk control.

Through the study of the development of logistics finance in our country, combined with small and medium-sized enterprises in the process of logistics financial business encountered bottleneck and risk, the potential problems for the in-depth analysis and summary, in contact with the latest research results at home and abroad on the basis of these problems puts forward some Suggestions. The purpose is to help small and medium-sized enterprises to develop more rapidly, so that the related business of logistics can be further carried out in China, and the logistics finance business can have a better future in our country.

\section{ACKNOWLEDGEMENTS}

This research is supported by National Natural Science Foundation of China (Grant No. 71702172), Humanities \& Social Sciences Research Foundation of Ministry of Education of China (Grant No. 15YJC630148), Distinguished Young Teacher Development Foundation of Zhengzhou University (1421326092), and Key Research Foundation of University Education in Henan province (17A520058). The authors would like to thank the editors and anonymous referees for their careful and fruitful comments to improve the quality of this paper.

\section{REFERENCES}

[1] Yan He, 2015.Attention to the public interest[J]. International financing, 4, pp.28-28.

[2] Peng Cui, Cong Li, 2013. Research on logistics and financial development in zhengzhou based on SWOT analysis [J]. Time finance, 11, pp.185-185. 
[3] Yan Cheng,2013. Analysis on logistics finance development in wuhan area [J]. Time finance, 11, pp.119-120.

[4] Peipei Tang, 2015.Analysis of the capital difficulties and countermeasures of joint-stock commercial Banks in China [J]. China chemical trade, 8, pp.189-191.

[5] Gang Wu, 2014. Yina Yao. Value creation of the combination of logistics finance and futures delivery [J]. Logistics technology, 10, pp.11-12.

[6] Daozhi Zhao, 2012. Mapeng Bai. Analysis of nrf-lc logistics financial model based on receivables management [J]. Journal of electronic science and technology university, 3, pp.37-38.

[7] Xuejian Chu,2013. Reflections on the prevention of credit risk in developing logistics finance [J]. Logistics technology, 2, pp.3.

[8] Suye Wang, 2015. Legal risks and circumvention measures for third-party logistics contracts in China [J]. Logistics technology. 4, pp.51-54.

[9] Shuikun Hong, 2015. The research and development of logistics financial problems [J]. Productivity research, 18, pp. 149-150.

[10] Weiguang Shen,Li Yu,2012.Research and revelation of supply chain finance of Aberdeen company [J]. Southwest finance, 4, pp.60-61.

[11] Siyu Geng, 2013. The idea of material Banks [J]. China industrial economic research, 3, pp.71-73.

[12] Shengrong Dong, Junlong Jia, 2012. Research on the innovation mechanism of supply chain financing risk control
[J]. Journal of Qingdao offshore seafarer vocational college, 4, pp.9-12.

[13] Puhe Liu, 2013. Operation mode of material banking operation and risk control research [J]. Management review, 9, pp.45.

[14] Xiaofeng Qin, 2012. Application of logistics finance in import and export trade [J]. Finance and economics, 10, pp.114-115.

[15] Gang Wang, 2015. Analysis of logistics financial jurisprudence $[\mathrm{J}]$. Cooperation economy and technology, 18, pp.191-192.

[16] Junhong Hao, 2012. A discussion on the risk identification and response of financing pledge of logistics enterprises [J]. China chief accountant, 5, pp.112-113.

[17] Nan Wang, 2012. Logistics finance analysis [J]. Zhejiang finance, 5, pp. 82.

[18] Lei Liu, 2013. New domain of logistics service [J]. China logistics and procurement, 2, pp.61-62.

[19] Wenhang Xing,2014. The collaborative development of modern finance and logistics [J]. Financial theory and practice, 6, pp.53-54.

[20] Shunxiang Teng, Zhizhong Peng, 2015. Reflections on the prevention of credit risk in developing logistics finance [J]. Logistics technology, 2, pp.131-132.

[21] Zheng Liu, 2014. The risk prevention of logistics financial services innovation and VMI system [J]. Research and discussion, 11, pp.39-40. 